\title{
Financial Anomalies: Evidence from Chinese A-share Markets
}

\author{
Roger $\mathrm{Su}$ \\ Auckland University of Technology, New Zealand \\ Private Bag 92006, Auckland, New Zealand \\ Tel: 64-9-921-9999-5058Ｅ-mail: roger.su@aut.ac.nz \\ Amitabh S. Dutta \\ Florida Institute of Technology, USA \\ 150 W. University Avenue, Melbourne, FL 32901, USA \\ E-mail: adutta@fit.edu \\ Mingwei Xu \\ Liaoning University, China \\ 66 Congshan Zhong Lu Road, Liaoning University, Shenyang, Huanggu District, China \\ E-mail: xumw128@126.com \\ Jun $\mathrm{Ma}$ \\ Chongqing International Trust Co., Ltd, Chongqing City, China \\ E-mail: majun80@gmail.com
}

Received: August 9, 2010

Accepted: August 30, 2010

doi:10.5539/ijef.v3n2p76

\begin{abstract}
The analysis of broad samples of equal-weighted and value-weighted returns of the Chinese security markets documents that abnormally high rates of return on small-capitalization stocks are to be observed during the month of March on both Shanghai and Shenzhen A-share markets. Different to the international experience of the January effect, the March effect can be seen as the turn-of-the-year effect in the Chinese security market as the national economic background and cultural background delay the turn-of-the-year from February to March.
\end{abstract}

Keywords: Financial Anomalies, Chinese A-share, March Effect, January Effect

\section{Introduction}

Financial anomalies such as day-of-the-week effect, turn-of-the-year effect and size effect etc. have been well documented. Evidence of such seasonality is available for the mature stock markets in the developed countries. However, research concerning such anomalies in emerging stock markets is scarce. The stock market in China poses an interesting study, as the market is less developed and it is relatively new. Moreover, the Chinese stock market is different from the market of Europe or the U.S. It has many unique features such as the institutional features, the culture's background and investment behaviours. This study will focus on the financial anomalies of the turn-of-the-year effect in the Chinese market.

The Chinese government sanctioned the opening of the Shanghai Stock Exchange (SHSE) in December 1990 and the Shenzhen Stock Exchange (SZSE) in July 1991. Since then, the Chinese Market has experienced rapid growth. The Chinese market has become the second largest market after Japan in Asia, and it is also the largest emerging market in the world.

Along with the swift development of the Chinese economy in recent years, the Chinese stock market has already become the focus of the world since China's entrance into the World Trade Organization (WTO) in 2001. In addition, the financial market had gradually begun to open to foreigner investors, which attracted a number of foreign banks and investment organizations into the Chinese financial market. An Increasing number of overseas investors have participated in investing in the Chinese stocks. To study Chinese share markets performance, that has become more and more important to both domestic Chinese and foreign investors.

Section two of this research provides hypothesis development; section three focuses on the literature review of financial anomalies. Section four discusses the data collection and methodology employed in this study while Section five discusses the test results. Section six discusses financial anomalies in the Chinese stock market. And, the last section contains the summary and conclusion. 


\section{Market Hypothesis}

The January effect was first introduced to the academia by Wachtel in 1942. It was again brought to academic attention by Rozeff and Kinney in 1976. After it was reintroduced in 1976 the January effect became widely known to the public (Haugen et al. 1996). Plenty of investors understood this celebrated anomaly of the financial markets or at least the majority of the professional investment community was very much aware of it. In other words, this information has been widely known. According to the Efficient Market Hypothesis, which asserts that financial markets are "informationally efficient", it is not possible for the January effect to consistently appear in the market, as the information about the January effect is well known and investors attempt to exploit it. Therefore, an injection of additional funds gets into the market before January, causing a rise in stock prices. As a result, the January effect should shift from January to December.

However, in fact, the January effect still appears even after its discovery. Haugen and Jorion (1996) studied the New York Stock Exchange from 1926 through 1993 and found no evidence that the January effect had disappeared from the New York Stock Exchange, even that the January effect is still going strong after its discovery. Furthermore, the authors provide two possible explanations for the persistence of the January effect. Firstly, the January effect is not a manifestation of market inefficiency, as it provides no opportunity for investors to earn abnormal rates of return, as the January returns of stock are tiny and trading costs are high. Secondly, the financial market is highly inefficient.

The reports from other countries are different. Gu (2006) found that the January effect exhibits a declining trend in five G7 countries. The effect is disappearing from Canada, France, Germany, Japan and United Kingdom. In particular, the evidence of the January effect on the U.K. market is getting much weaker than before.

\section{Literature Review}

Fama (1965) defined efficient market hypothesis into three common forms which are weak form efficiency, semi-strong form efficiency and strong form efficiency. However, the existence of seasonality in security markets has implications for both the study of market efficiency and tests involving return models. The existence of seasonal asset returns may be an indicator of market inefficiencies.

The January effect or turn-of-the-year effect is a good example of seasonal anomalies in security markets throughout the world. At the turn-of-the-year, certain types of securities tend to produce positive abnormal returns. Stock prices have tended to rise markedly during the period starting on the last trading day of December and ending on the fifth trading day of January.

Rozeff and Kinney (1976) found a seasonal pattern in the New York Stock Exchange (NYSE) index over the period of 1904 to 1974. In particular, the average monthly return in January was about 3.5 percent, while the average return in other months was just 0.5 percent. The average return in January appeared to be about seven times higher than returns for other months.

Keim (1983) found that the abnormal return in January is related to the stock market capitalization. In particular, small capitalization stocks outperform large capitalization stocks in January, as small capitalization stocks post a higher abnormal return than large capitalization stocks. Reiganum (1983) confirmed that the January effect is largely a small capitalization phenomenon.

Besides the US market, Berges and McConnell (1984), through analysis of the Canadian stock market from 1973 to 1980, found that the January effect in Canada not only appears in small firms but large firms as well. A smallest-firm portfolio earns an average return of 8.15 percent in January and 1.13 percent for the rest of the year, while the largest-firm portfolio attains an average return of 5.4 percent in January and 0.83 percent for the rest of the year. Compared with the U.S market where the January effect is only pronounced for small capitalization, the explanation for the Canadian stock market is that most Canadian stocks are small compared to the U.S stocks and the average return of large stock in Canada may be equivalent to small or medium stock in the U.S. Athanassakos (1997) supported the finding that the January effect in Canada is not only a small firms phenomenon and suggested that the January effect is the result of the behaviour of institutional investors.

Clare et al. (1995) examined the seasonal fluctuations in the UK equity market. The result reveals that returns on the FT-A All share index exhibited a significant seasonality in January and the seasonal variation is robust across size sorted portfolios.

Brown, Keim et al. (1983) studied Australian stocks for the period 1958 to 1981. A January and August seasonal anomaly has been found. This finding strongly supports the Tax-Loss-Selling Hypothesis because Australia has similar tax laws to the U.S but a July tax year.

After examining the New Zealand stock market, Raj and Thurston (1994) indicate there is no January effect in the New Zealand stock market. However, Hasan and Raj (2001) using stock data ranging from 1983 to 1993 claimed that there is a January effect in the New Zealand stock market. 
Kato and Schallheim (1985) examined the Tokyo Stock Exchange in Japan. January and June anomalies were found. The explanation for the January-June anomalies is that they are due to bonuses peculiar in Japanese society. Reyes (2001) supports this finding and adds that both January and June effects are small-capitalization stock phenomena.

Tong (1992) claimed that the January effect is not observed either in the South Korean market or Taiwanese market. However, a Lunar New Year effect in the Taiwanese market was found, but this does not seem to be related to the Tax-Loss-Selling-Hypothesis as the Taiwanese market had no capital gains tax during the sample period of 1980 to 1988. The Lunar New Year effect on Taiwan's market may be due to liquidity reasons.

Raj and Kumari (2006) examined the Bombay Stock Exchange (BSE) and National Stock Exchange (NSE) in India. The January effect was not found in the Indian stock market but April seasonal returns were found to be higher than nine other months. The April seasonal return occurs due to Tax-Loss-Selling as the financial year ends on 31st March and a capital gains tax is imposed by the Indian government.

Extending the January effect into the Chinese market, Ong (2006) studied Chinese seasonal anomalies including the turn-of-the-year effect, the turn-of-the-month effect and the day-of-the-week effect. They found that the January effect does not appear in either the Shenzhen or Shanghai share markets. But a high return in February has been found. Although the February effect is not statistically significant for the Chinese stock markets, the average returns posted in February are positive and appear substantially higher than those of the non-February months. This February effect may suggest that the turn-of-the-year for Chinese stock markets may occur during the Chinese Lunar New Year. After examining the calendar effects in the Chinese stock market, Gao and Kling (2005) also found a monthly pattern of market return in both Shenzhen and Shanghai stock exchanges with the highest return in February, but it is insignificant as well. The explanation for the seasonal high return in February in China is that February is the turn-of-the-year in China, as the Chinese Lunar New Year usually begins in late January or sometime during February, rather than at the turn of the calendar year.

However, Zhang and Sun (2003) by examining the seasonal anomalies in China, reported that there is no January effect or a February Chinese New Year effect on the Chinese stock market. But a significant and positive March effect was found. The explanation is interesting in that they consider that the March effect in China reveals the political nature of financial anomalies in the country. March is the political high season in China and in March political window-dressing is caused by political manoeuvres by the Chinese government, resulting in a higher March return in the Chinese stock market.

As we talked above, Chinese share market performance has become significant to investors globally, it is necessary to identify the seasonal anomalies in China. This researcher aims to check whether there is January Effect, or February Effect or March Effect in Chinese markets.

\section{Data and Methodology}

In this study, we are going to use value-weighted indices and equal-weighted portfolio data to analyse monthly seasonality in the Chinese stock market. According to Lakonishok and Smidt (1988), Schwert (1990) and Haug and Hirschey (2006), they found that the evidence of January effect is stronger by using equal-weighted data than value-weighted data. Because the equal-weighted index represented a simple average of the stock prices for all listed companies, the equal-weighted index gave small companies greater relative influence than would be true in a value-weighted index. Lakonishok and Smidt studied monthly returns for Dow Jones Industrial Average (DJIA), a price-weighted market index of 30 largest-companies and found no evidence of a January effect. Schwert found little evidence of monthly seasonality in value-weighted indices by studying the Center for Research in Security Prices (CRSP) which small-company stocks have little weight. Haug and Hirschey studied both equity-weighted and value-weighted indices of CRSP from period 1802 to 2004. They found that average value-weighted portfolio returns for January were 1.1 percent and for the other 11 months of the year the return was 0.7 percent. However, by using equal-weighted portfolio returns, the average return for January was 6.05 percent versus average of 0.91 percent for other months.

To test such an effect, that is, using an equal-weighted index is better than a value-weighted index, will determine if there is a January effect as a small capitalization phenomenom Most researchers tested seasonal anomalies in the Chinese market by using value-weighted indices and researchers reported that there is no evidence of a January effect or a Chinese New Year effect.

In this case, we are going to use both value-weighted indices and equal-weighted portfolio data to examine the monthly seasonality in Chinese A-share stock markets. There are A-share - shares can be traded in CNY for domestic investors; B-share - shares can only be traded in USD for foreign investors prior to 2001; B-share markets became available to domestic investors after 2001. Here we have only chosen both Chinese A-share markets:

SHA Share Index: Constituents for SHA Share Index are all listed A shares at Shanghai Stock Exchange.

SZA Share Index: Constituents for SHA Share Index are all listed A shares at Shenzhen Stock Exchange. 
Two different variables are used to analyse monthly seasonality; these are the stock return and the market capitalization. The monthly share price has been collected from 1994 to 2006 for each stock, and is used for monthly seasonality analysis. The market value has been collected from 1993 to 2005 for each stock, and it is used to determine size classes for the listed companies. The monthly data is sourced from the DataStream database. All data is carefully screened to ensure any missing values of the indices are handled correctly.

Shanghai A-share (SHA) and Shenzhen A-share (SZA) indices are published by the Shanghai Stock Exchange and Shenzhen Stock Exchange respectively and all of the indices are value-weighted indices where large companies dominate the index. Therefore, in testing such an effect by using value-weighted index data, it might be difficult to observe the seasonal anomaly in the Chinese markets. In this case, creating an equal-weighted portfolio index is necessary for monthly seasonality analysis.

Also, in order to determine the size effect, the firms listed on the market are ranked into five size classes. The last day of a year market value is used to determine firms' size for the next year. Ranking the firms' market value by size from the lowest to the highest and dividing into five size classes, each class had 20 percent of the total firms. An equal-weighted portfolio index is created for each size class. As new firms have been listed every year, we add these firms into the equal-weighted portfolio. Table 1 shows the number of companies that we used as our sample to created equal-weighted indices in each year for each market.

The monthly returns are calculated as:

$R_{t}=\operatorname{Ln}\left(\frac{P_{t}}{p_{t-1}}\right)$

Where:

$$
\begin{aligned}
& R_{t} \text { is stock return at month } t . \\
& P_{t} \text { is share price at month } t .
\end{aligned}
$$

The market values are calculated as:

$M V_{t}=P_{t} \times S_{t}$

Where:

$M V_{t}$ is market value at time $t$ which represents the last day of the year.

$P_{t}$ is share price at time $t$.

$S_{t}$ is number of shares at time $t$

The equal-weighted portfolio returns are calculated as:

$$
I_{j t}=\frac{\sum_{i=1}^{N} R_{i t}}{N}
$$

Where:

$$
\begin{aligned}
& I_{j t} \text { is average return for all the companies' returns at time t for portfolio } j . \\
& R_{i t} \text { is the monthly return for company i in month } t . \\
& N \text { is number of companies. }
\end{aligned}
$$

This paper uses the linear regression model to examine the monthly seasonality. To identify any possible trend of the January effect, one needs to compare the January average return with the average of the non-January months.

Model:

$I_{j t}=\partial+\sum_{t=1}^{11} \beta_{t} d+\varepsilon_{t}$

Where:

$I_{j t}$ is the monthly return in month $t$ for portfolio $j$ or index $j$.

The $\partial$ is the intercept of the regression which measures the average

monthly returns.

The regression slop $\beta_{t}$ measures the difference between the expected return for January and the other months of the year. 
$d$ is a dummy variable which indicates monthly average return related to its month.

$\varepsilon_{t}$ is an error term.

Because of the government interference, the share structure and the investment behaviour etc. make the Chinese market unusual compared with other mature markets. For example, according to our equal-weighted portfolio data, in some periods of time the monthly return even reached 91.01 percent for the smallest size group of Shanghai A-share in August, 1994. For medium, big, large and largest size groups the highest returns are 84.78 percent, 101.61 percent, 92.06 percent and 95.68 percent respectively. The largest slumps for small, medium, big, large and largest size group were -38.79 percent, -38.94 percent, -38.66 percent, -35.89 percent and -33.98 percent respectively, in July, 1994. By using a regression analysis we can test the monthly seasonality. But these outliers may unduly influence and/or bias the measure of average return, and lead to erroneous conclusions. In order to isolate any such effect it is necessary to set up criteria to analyse stock returns. We assume all the monthly returns are random and the returns on each class follow a normal distribution, therefore 95 percent of returns fall into two standard deviations away from the mean and we believe the return in the 95 percent range is normal in a market. The mean and standard deviation for each group size is calculated.

The standard deviations are calculated as:

$\sigma=\sqrt{\frac{\sum(x-\bar{x})^{2}}{N}}$

Where: $\sigma$ is the standard deviation.

$\underline{x}$ stands for an entire list of numbers.

$\bar{x}$ simply means the arithmetic mean of all the numbers in the list.

$N$ stands for how many numbers there are in the list.

The $95 \%$ range is:

Uplevel $=2 \sigma+\bar{x}$

Lowlevel $=-2 \sigma+\bar{x}$

Where: $\sigma$ is the standard deviation.

$\bar{x}$ simply means the arithmetic mean of all the numbers in the list.

After eliminating the outliers of stock returns outside of the $95 \%$ range, we found that these outliers are quite consistent with the government interference on the stock markets, as we mention before. For all the four markets, the outliers are concentrated in July 1994, August 1994, April 1996 and June 1996. For Shenzhen A-share, there are more outliers that have been deleted. This may suggest that the Shenzhen A-share market is more volatile than the Shanghai A-share market. In other words, the events occurring on the Shenzhen A-share market persisted longer than on the Shanghai A-share market. Table 2 shows the outliers which are out of the 95 percent range and are eliminated from each market.

\section{Results}

Overall, according to our test results, we find that there is no evidence of January effect in the Chinese stock market. Contrary to the international experience of January effect, the Chinese A-share markets post lower average returns in January. Some researchers suggest that there is a February effect as almost all of the Chinese New Year falls into February, so February could be seen as turn-of-the-year in China. According to this study, the evidence of February effect is clear; however, the mean returns in February are the second highest returns except for those in March. However, a robust and positive March effect has been found and it is significant at the 10 percent level for both A-share markets by using adjusted data. In particular, adjusted equal-weighted data shows a stronger March effect than adjusted value-weighted data. Evidence is provided that the monthly returns in March have larger means relative to the other months, and that the relation between abnormal returns and size is always negative and more prominent in March than any other month.

The size effect has been confirmed in A-share markets as smaller size groups have higher returns than larger size groups.

Comparing the unadjusted data and adjusted data, we found that data adjustment is necessary as the Chinese stock market is a policy-driven market which is driven by the government's interference, thus some incredible returns appear on the emerging market. These incredible returns can be seen as outliers and these outliers greatly influenced the results of the monthly anomaly analysis. 


\subsection{Test results using value-weighted returns for A-shares}

The statistical test results, using unadjusted value-weighted data, show that there is generally no January effect in either SHA or SZA share market (see Table 3, Panel 1). The fifteen average January returns on SHA and SZA are -0.04 percent and -0.17 percent respectively; both A-share markets have posted lower mean returns in January compared to the other months. After using the adjusted data value-weighted data, the results on Table 3, Panel 2 also show that the mean return in January is lower than other months. As a result, we confirmed that there is no January effect existing in the Chinese A-share markets with value-weighted data. Contrary to the international experience of January effect, the Chinese A-share markets post lower average returns in January.

Some researchers suggest that there is a Chinese New Year effect in the Chinese stock market as Chinese New Year is the-turn-of-year in China. The turn-of-the-year in China is not from the beginning of the calendar year. The Chinese New Year tends to occur in either late January or February and most years the Chinese New Year falls in February. In other words, the highest return should occur in February in the Chinese stock market, based on the international experience that highest mean returns occur in the month of the turn-of-the-year. Therefore, the February effect has been tested as well. The test result, by using unadjusted data in Table 4, Panel 1 shows that there are different results between SHA and SZA. The test result for SHA shows that the mean return for February is positive and higher than some other months, but it is not the highest one. However, the test result for SZA shows that the highest mean return is in February, but it is insignificant. These results make the turn-of-the-year effect more elusive on the Chinese stock market. We expected the test results on both A-share markets to be consistent as we believe the investment behaviour of all Chinese domestic investors is similar, so the highest mean returns should consistently appear in the same month, but the test results by using unadjusted data suggest that there is different investment behaviour between SHA and SZA share markets. In contrast, by using adjusted data for the February test, Table 4, Panel 2 shows that after adjusting the data, the test results for both A-share markets are consistent as the results suggest that there are positive mean returns in February for both A-share markets; however, we did not find evidence of February effect.

Furthermore, we tested for the existence of the March effect by using both unadjusted data and adjusted data value-weighted data. By using the unadjusted data, the results in Table 5, Panel 1 on SHA share market, show that March has the highest mean returns of all months. The test results on SZA suggested that March is not the highest return and the highest return is February. However, a March effect is found by using adjusted value-weighted data though the evidence is weak (see Table 5, Panel 2). Both A-share markets show that March has the highest mean returns and that they are significantly higher than some months. For SHA the mean returns in March are 4.48 percent and are significantly higher than June, August, October and December at the 10 percent level of significance.

\subsection{Test results using equal-weighted portfolio returns for A-shares}

As we rank the A-shares into five portfolio size classes, we find a robust size effect for both SHA and SZA share markets (see Table 6). Furthermore, the results support the size effect theory that small-capitalization firms have higher returns than large-capitalization firms, and also higher return companies with a higher risk. The average return for portfolios of the smallest firms on the SHA share market is 0.72 percent with a 12.03 percent standard deviation versus negative 0.02 percent with an 11.11 percent standard deviation for largest firm. The return on portfolios of the smallest firms on the SZA share market is 0.66 percent with a 12.76 percent stand deviation versus a negative 0.22 percent average return on portfolios of the largest firms with 10.08 percent standard deviation. Interestingly, small portfolio size groups on the SZA share market are more risky than on the SHA share market, but the returns on SZA shares are not higher than SHA. In the aspect of large portfolio size groups, SHA shares have a higher risk than SZA shares.

According to our unadjusted equal-weighted portfolio results from Table 7, we found that there is no evidence of March effect on the SZA share market. However, SHA share market shows weak evidence of March effect in the small size portfolio class as the returns in March are significantly higher than June, July, October and December. But the result also suggested that the mean returns in March are not the highest returns. Both A-share markets indicate the highest return is August. By checking the data we found there is an outlier which occurs in August, 1994. The returns are 91.0 percent and 66.86 percent for the smallest portfolio group in SHA and SZA share markets respectively. For the largest portfolio group the August returns are 95.58 percent and 42.46 percent in SHA and SZA respectively. These outliers highly influence the regression test. Also as we mentioned before, in this period of time the government interfered in the market, making the return unusual. So, eliminating the outliers is necessary on the A-share market.

By using adjusted, equal-weighted data, a robust March effect is found in both SHA and SZA share markets (see Table 8). For the SHA share market, the mean return in March on the smallest portfolio size group is 6.93 percent which is significantly higher than almost all the other months at the 10 percent level of significance, except February 
and May. As the portfolio size increases, the mean returns in March are decreasing and the evidence of March effect is getting weaker and in some months becomes insignificant in contrast to the smallest size group. The March return on the SZA share market is 5.76 percent, which is significantly higher than almost all the other months except for February and May. The mean returns in March have a negative relationship with their size. Increasing the size makes the evidence of March effect weaker.

\section{Conclusion}

Seasonal anomalies are well documented in developed stock markets. One famous example of seasonal anomalies is the January effect or turn-of-the-year effect. This research focuses on the turn-of-the-year effect on the Chinese stock market. This research covers the two Chinese stock markets including SHA and SZA share markets and the seasonal anomaly has been tested by using value-weighted indices and equal-weighted portfolios.

In this study, we found no evidence of the January effect in the Chinese stock market, in contrast to other international markets. However, a significant March effect is found by using either adjusted value-weighted or adjusted equal-weighted data on both SHA and SZA share markets. In addition, the adjusted equal-weighted data shows a robust March effect and this finding strongly supports the theory that the turn-of-the-year effect is a small capitalization phenomenon. Although February can be seen as the turn-of-the-year in China, as the Chinese Lunar New Year occurs in late January and February, we believe the March effect is the turn-of-the-year in China as the national economic background and cultural background delay the turn-of-the-year to March.

\section{References}

Athanassakos, G. (1997). Firm size, stock return seasonality, and the trading pattern of individual and institutional investors: The Canadian experience. The Journal of Investing 6(3): 75-86.

Athanassakos, G. \& Schnabel, J. A. (1994). Professional portfolio managers and the January effect: theory and evidence. Review of Financial Economics 4(1): 79-91.

Berges, A., McConnell, J., et al. (1984). The Turn-of-the Year in Canada. Journal of Finance 39: 185-192.

Bhabra, H., Dhillion, U., et al. (1999). A November Effect? Revisiting the Tax-Loss-Selling Hypothesis. Financial Management 28(4): 88-93.

Blume, M. E. \& Stambaugh, R. F. (1983).Biases in Computed Returns: An Application to the Size Effect. Journal of Financial Economics 12(3): 387-392.

Brown, P., Keim, D. B., et al. (1983). Stock Return Seasonalities and the Tax-Loss Selling Hypothesis: Analysis of the Arguments and Australian Evidence. Journal of Financial Economics (12): 105-128.

Chow, G. \& Lawler, C. (2003). A time series analysis of the Shanghai and New York stock price indices. Annals of Economics and Finance 4: 17-36.

Clare, A. D., Psaradakis, Z., et al. (1995). An analysis of seasonality in the U.K. equity market. The Economic Journal. London 105(4): 398-410.

Eun, C. S. \& Huang, W. (2002). Asset pricing in China: is there a logic? Working paper. Georgia Institute of Technology.

Fama, E. (1965). The Behaviour of Stock Market Prices. Journal of Business 38: 34-105.

Fedenia, M., R.A, C. C. Haugen \& D.C Cho. (1990). Professional investor Re-entry as the January Effect. Working paper: University of Wisconsin-Madison.

Gao, L. \& Kling, G. (2005). Calendar Effects in Chinese Stock Market. Annals of Economics and Finance 6:75-88.

Goyal, A., Perignon, C.\& Villa, C. (2007). How Common are Common Return Factors Across Nyse and Nasdaq. Working paper. Emory University.

$\mathrm{Gu}$, A. Y. (2003). A trend towards being normal: the share experience on the Shanghai stock exchange. Applied Financial Economics 13: 379-385.

Gu, Y. (2006). The declining January effect: experience of five G7 countries. Academy of Accounting and Financial Studies Journal 10(1): pg. 41-49.

Hasan, T. \& Raj, M. (2001). An examination of the tax loss selling behaviour in a de-regulated Pacific financial market. American Business Review 19(2): 100-105.

Haug, M. and Hirschey, M. (2006). The January Effect. Financial Analysis Journal 62(5).

Haugen, R. A. \& Jorion, P. (1996). The January Effect: Still There after All These Years. Financial Analysis Journal 52(1): 11-27.

Haugen, R. A. \& J. Lakonishok. (1988). The Incredible January Effect: The Stock Market's Unsolved Mystery. Globe and Mail, Homewood. 
Heilman, S. (2002). The Chinese Stock Market: Pitfalls of A Policy-Driven Market. China Analysis (No. 15).

Johnsion, K. \& Paul, C. (2005). Further Evidence of the November Effect. Journal of Economics and Finance 29(2): $37-48$.

Kato, K. \& Schallheim, J. S. (1985). Seasonal and Size Anomalies in the Japanese Stock Market. Journal of Financial and Quantitative Analysis 20(2):243-261.

Keim, D. B. (1983). Size-Related Anomalies and Stock Return Seasonality: Further Empirical Evidence. Journal of Financial Economics 12(1):13-24

Lakonishok, J. \& Smidt, S. (1988). Are Seasonal Anomalies Real? A Ninety-Year Perspective. Review of Financial Studies 1(4): 403-425.

Lin, Q. (2005). Administrative changepoint detection in quality control and dynamical systems. Journal of the Royal Statistical Society B(57): 613-658.

Lu, H. \& Ma, Q. (2004). Do Earnings Explain the January Effect. Los Angeles, University of Southern California. Working paper.

Mei, J., Scheinkman, J. A. \& Wei, X. (2005). Speculative trading and stock prices: evidence from Chinese a-b share premier. ANNALS OF ECONOMICS AND FINANCE ,10-2, 225- 255.

O'Neal, E. S. (2001). Window Dressing and Equity Fund, Babcock Graduate school of management, Wake forest university.

Ong, L. (2006). Seasonalities in China`s Stock Markets: Cultural or Structural? International Monetary Fund Working paper.

Raj, M. \& Kumari, D. (2006). Day-of-the-week and other market anomalies in the Indian stock market. International Journal of Emerging Markets 1(3):18-35.

Raj, M. \& Thurston, D. (1994). January or April? Tests of the turn-of-the-year effect in the New Zealand stock market. Applied Economic Letters 1: 81-83.

Reinganum, M. (1983). The Anomalous Stock Market Behaviour of Small Firms in January: Empirical Tests for Tax-Loss Selling Effect. Journal of Financial Economics 17: 59-82.

Reinganum, M. R. \& Shapiro, A. C. (1987). Taxes and stock return seasonality: Evidence from the London Stock Exchange. Journal of Business 60: 281-295.

Reyes, M. G. (2001). Asymmetric volatility spillover in the Tokyo Stock Exchange. Journal of Economics and Finance 25(2).

Ritter, J. R. (1988). The Buying and Selling Behaviour of Individual Investors at the Turn of the Year. Journal of Finance 43(3): 701-719.

Rozeff, M. S. \& Kinney, W. R. (1976). Capital Market Seasonality: The Case of Stock Returns. Journal of Financial Economics 3(4): 379-402.

Schwert, G. W. (1990). Indexes of U.S. Stock Prices from 1802 to 1987. Journal of business 63(3): 399-426.

Sias, R. W. \& Starks, L. T. (1997). Institutions and individuals at the turn-of-the-year. The Journal of Finance 52(4): 1543-1562.

Tong, W. (1992). An analysis of the January effect of United States, Taiwan and South Korean stock returns. Asia Pacific Journal of Management 9(2): 120-189.

Vanden, B. \& Wessels, R. E. (1985). Stock Market Seasonality and Taxes: An Examination of the Tax-Loss Selling Hypothesis. Journal of Business Finance \& Accounting 12(4): 515-521.

Wachtel, S. (1942). Certain Observations on Seasonal Movements in Stock Prices. The Journal of Business 15(2): 184-193.

Wang, F. \& Xu, Y. (2003). What determines Chinese Market returns? School of Management, The University of Texas at Dallas.

Zhang, Z., Sun, W. \& Hua, W. (2003). Financial Anomalies in Emerging Markets: The Case of China, Working paper, Business school, Durham University. 
Table 1. The number of companies that we used as our sample to created equal-weighted indexes in each year for each market.

\begin{tabular}{|lcc|}
\hline & SHA No. of S & SZA No. of S \\
\hline $\mathbf{1 9 9 3}$ & 87 & 57 \\
$\mathbf{1 9 9 4}$ & 149 & 94 \\
$\mathbf{1 9 9 5}$ & 163 & 99 \\
$\mathbf{1 9 9 6}$ & 247 & 175 \\
$\mathbf{1 9 9 7}$ & 322 & 272 \\
$\mathbf{1 9 9 8}$ & 367 & 318 \\
$\mathbf{1 9 9 9}$ & 406 & 362 \\
$\mathbf{2 0 0 0}$ & 484 & 407 \\
$\mathbf{2 0 0 1}$ & 551 & 408 \\
$\mathbf{2 0 0 2}$ & 618 & 409 \\
$\mathbf{2 0 0 3}$ & 681 & 409 \\
$\mathbf{2 0 0 4}$ & 739 & 445 \\
$\mathbf{2 0 0 5}$ & 742 & 454 \\
$\mathbf{2 0 0 6}$ & 755 & 500 \\
\hline
\end{tabular}

Note: Firstly, we rank the stocks by market value from smallest to largest for each year. Secondly, we separate the stocks into five size classes according its market value and let each group have $20 \%$ of the total number of firms. Thirdly, we created a monthly equal-weighted portfolio return for each year.

Table 2. The outliers

\begin{tabular}{|c|c|c|c|c|c|c|c|c|c|}
\hline \multicolumn{2}{|c|}{ SHA 1} & \multicolumn{2}{|c|}{ SHA 2} & \multicolumn{2}{|c|}{ SHA 3} & \multicolumn{2}{|c|}{ SHA 4} & \multicolumn{2}{|c|}{ SHA 5} \\
\hline Date & Returns & Date & Returns & Date & Returns & Date & Returns & Date & Returns \\
\hline 1994-7-29 & $-38.79 \%$ & 1994-7-29 & $-38.94 \%$ & 1994-7-29 & $-38.66 \%$ & 1994-7-29 & $-35.89 \%$ & 1994-7-29 & $-33.98 \%$ \\
\hline 1994-8-31 & $91.01 \%$ & $1994-8-31$ & $84.78 \%$ & 1994-8-31 & $101.61 \%$ & 1994-8-31 & $92.06 \%$ & 1994-8-31 & $95.58 \%$ \\
\hline $1996-4-30$ & $25.07 \%$ & $1996-4-30$ & $22.61 \%$ & $1996-4-30$ & $22.77 \%$ & $1996-4-30$ & $23.74 \%$ & 1999-6-30 & $28.43 \%$ \\
\hline $1999-6-30$ & $25.59 \%$ & $1999-6-30$ & $25.16 \%$ & 1999-6-30 & $29.86 \%$ & 1999-6-30 & $27.61 \%$ & & \\
\hline \multicolumn{2}{|c|}{ SZA 1} & \multicolumn{2}{|c|}{ SZA 2} & \multicolumn{2}{|c|}{ SZA 3} & \multicolumn{2}{|c|}{ SZA 4} & \multicolumn{2}{|c|}{ SZA 5} \\
\hline Date & Returns & Date & Returns & Date & Returns & Date & Returns & Date & Returns \\
\hline 1994-6-30 & $-25.37 \%$ & 1994-6-30 & $-24.31 \%$ & 1994-7-29 & $-26.69 \%$ & 1994-7-29 & $-22.46 \%$ & 1994-3-31 & $-22.53 \%$ \\
\hline $1994-7-29$ & $-30.24 \%$ & $1994-7-29$ & $-30.22 \%$ & 1994-8-31 & $60.10 \%$ & 1994-8-31 & $47.46 \%$ & 1994-8-31 & $42.13 \%$ \\
\hline 1994-8-31 & $66.86 \%$ & $1994-8-31$ & $67.87 \%$ & $1994-10-31$ & $-25.88 \%$ & $1994-10-31$ & $-27.30 \%$ & $1994-10-31$ & $-27.38 \%$ \\
\hline $1994-9-30$ & $34.71 \%$ & $1996-4-30$ & $33.86 \%$ & $1996-4-30$ & $35.28 \%$ & $1996-4-30$ & $40.23 \%$ & $1996-4-30$ & $34.49 \%$ \\
\hline $1996-4-30$ & $34.34 \%$ & 1996-7-31 & $35.30 \%$ & $1996-7-31$ & $33.12 \%$ & $1996-7-31$ & $30.77 \%$ & $1996-7-31$ & $29.69 \%$ \\
\hline $1996-7-31$ & $35.29 \%$ & $1996-10-31$ & $40.33 \%$ & $1996-10-31$ & $34.49 \%$ & $1996-10-31$ & $37.45 \%$ & $1996-10-31$ & $29.06 \%$ \\
\hline $1996-10-31$ & $44.58 \%$ & $1996-12-31$ & $-35.59 \%$ & $1996-12-31$ & $-31.87 \%$ & $1996-12-31$ & $-31.02 \%$ & $1996-12-31$ & $-28.59 \%$ \\
\hline $1996-12-31$ & $-42.72 \%$ & 1999-6-30 & $26.40 \%$ & 1999-6-30 & $29.26 \%$ & 1999-6-30 & $26.75 \%$ & 1999-6-30 & $31.74 \%$ \\
\hline 1999-6-30 & $26.77 \%$ & & & & & & & & \\
\hline
\end{tabular}

Note: 1, Size 1 represents the smallest capitalization stocks and size 5 represents the largest capitalization stocks.

2 , We assume all the monthly returns are normal distributions, therefore, $95 \%$ of returns fall into two standard deviations away from the mean. We believe the $95 \%$ range of returns is normal returns in the Chinese markets. The returns out of $95 \%$ range can be seen as outliers as these abnormal returns unduly influence and/or bias the regression test results. We tested the financial anomaly by using adjusted data from which the outliers were eliminated.

Table 3. Test results by using value-weighted data for January test on A-shares

Panel 1: Estimated coefficients by unadjusted data-JANUARY, 1994-2006

\begin{tabular}{|c|cc|cc|}
\hline & \multicolumn{2}{|c|}{ SHA } & \multicolumn{2}{c|}{ SZA } \\
\hline Month & Coefficients & P-value & Coefficients & P-value \\
\hline Constant & $-0.04 \%$ & 0.988 & $-0.17 \%$ & 0.951 \\
Feb. & $2.45 \%$ & 0.521 & $3.21 \%$ & 0.411 \\
Mar. & $4.52 \%$ & 0.237 & $2.86 \%$ & 0.463 \\
Apr. & $0.24 \%$ & 0.949 & $0.77 \%$ & 0.843 \\
May. & $1.95 \%$ & 0.610 & $2.73 \%$ & 0.483 \\
Jun. & $-0.76 \%$ & 0.842 & $-1.43 \%$ & 0.713 \\
Jul. & $0.41 \%$ & 0.914 & $1.96 \%$ & 0.615 \\
Aug. & $3.27 \%$ & 0.392 & $1.39 \%$ & 0.722 \\
Sep. & $-0.42 \%$ & 0.6913 & $-0.15 \%$ & 0.970 \\
Oct. & $-1.52 \%$ & 0.629 & $0.22 \%$ & 0.954 \\
Nov. & $1.85 \%$ & 0.549 & $1.14 \%$ & 0.770 \\
Dec. & $-2.29 \%$ & & $-4.03 \%$ & 0.302 \\
\hline
\end{tabular}

Note: 1, constant represents January

2, the results show that there is no January effect in SHA and SZA by using unadjusted value-weighted data.

Panel 2: Estimated coefficients by adjusted data-JANUARY, 1994-2006 


\begin{tabular}{|c|cc|cc|}
\hline & \multicolumn{2}{|c|}{ SHA } & \multicolumn{2}{|c|}{ SZA } \\
\hline Month & Coefficients & P-value & Coefficients & P-value \\
\hline Constant & $-0.04 \%$ & 0.986 & $-0.17 \%$ & 0.935 \\
Feb. & $2.45 \%$ & 0.428 & $3.21 \%$ & 0.276 \\
Mar. & $4.52 \%$ & 0.144 & $4.73 \%$ & 0.117 \\
Apr. & $0.24 \%$ & 0.937 & $-2.26 \%$ & 0.451 \\
May. & $0.40 \%$ & 0.898 & $2.73 \%$ & 0.353 \\
Jun. & $-0.76 \%$ & 0.805 & $-3.26 \%$ & 0.279 \\
Jul. & $0.41 \%$ & 0.894 & $-0.95 \%$ & 0.751 \\
Aug. & $-1.43 \%$ & 0.649 & $-0.83 \%$ & 0.782 \\
Sep. & $-0.42 \%$ & 0.892 & $-0.15 \%$ & 0.961 \\
Oct. & $-1.52 \%$ & 0.624 & $-0.29 \%$ & 0.925 \\
Nov. & $1.85 \%$ & 0.550 & $1.14 \%$ & 0.698 \\
Dec. & $-2.89 \%$ & 0.372 & $-2.23 \%$ & 0.457 \\
\hline
\end{tabular}

Note: 1 , constant represents January

2, the results show that there is no January effect in SHA and SZA by using unadjusted value-weighted data.

Table 4. Test results by using value-weighted data for February test on A-shares

Panel 1: Estimated coefficients by unadjusted data - FEBRUARY, 1994-2006

\begin{tabular}{|c|cc|cc|}
\hline & \multicolumn{2}{|c|}{ SHA } & \multicolumn{2}{c|}{ SZA } \\
\hline Month & Coefficients & P-value & Coefficients & P-value \\
\hline Constant & $2.41 \%$ & 0.372 & $3.04 \%$ & 0.271 \\
Jan. & $-2.45 \%$ & 0.521 & $-3.21 \%$ & 0.411 \\
Mar. & $2.08 \%$ & 0.587 & $-0.35 \%$ & 0.929 \\
Apr. & $-2.21 \%$ & 0.563 & $-2.44 \%$ & 0.532 \\
May. & $-0.50 \%$ & 0.895 & $-0.47 \%$ & 0.903 \\
Jun. & $-3.21 \%$ & 0.401 & $-4.64 \%$ & 0.235 \\
Jul. & $-2.04 \%$ & 0.593 & $-1.25 \%$ & 0.749 \\
Aug. & $0.82 \%$ & 0.830 & $-1.82 \%$ & 0.640 \\
Sep. & $-2.87 \%$ & 0.453 & $-3.35 \%$ & 0.390 \\
Oct. & $-3.96 \%$ & 0.300 & $-2.98 \%$ & 0.444 \\
Nov. & $-0.60 \%$ & 0.874 & $-2.07 \%$ & 0.596 \\
Dec. & $-4.74 \%$ & 0.215 & $-7.24 \%$ & $\mathbf{0 . 0 6 5}$ \\
\hline
\end{tabular}

Note: $1, *$ significant level at $10 \%$

2, constant represent February

3, by using unadjusted value-Weighted data, the results show that there is no significant February effect in both SHA and SZA.

Panel 2: Estimated coefficients by adjusted data - FEBRUARY, 1994-2006

\begin{tabular}{|c|cc|cc|}
\hline & \multicolumn{2}{|c|}{ SHA } & \multicolumn{2}{c|}{ SZA } \\
\hline Month & Coefficients & P-value & Coefficients & P-value \\
\hline Constant & $2.41 \%$ & 0.271 & $3.04 \%$ & 0.145 \\
Jan. & $-2.45 \%$ & 0.428 & $-3.21 \%$ & 0.276 \\
Mar. & $2.08 \%$ & 0.502 & $1.52 \%$ & 0.612 \\
Apr. & $-2.21 \%$ & 0.475 & $-5.47 \%$ & $\mathbf{0 . 0 7 0}$ \\
May. & $-2.04 \%$ & 0.517 & $-0.47 \%$ & 0.872 \\
Jun. & $-3.21 \%$ & 0.299 & $-6.47 \%$ & $\mathbf{0 . 0 3 3}$ \\
Jul. & $-2.04 \%$ & 0.509 & $-4.16 \%$ & 0.167 \\
Aug. & $-3.88 \%$ & 0.219 & $-4.04 \%$ & 0.180 \\
Sep. & $-2.87 \%$ & 0.354 & $-3.35 \%$ & 0.255 \\
Oct. & $-3.96 \%$ & 0.201 & $-3.50 \%$ & 0.256 \\
Nov. & $-0.60 \%$ & 0.845 & $-2.07 \%$ & 0.482 \\
Dec. & $-5.33 \%$ & $\mathbf{0 . 1 0 0} *$ & $-5.44 \%$ & $\mathbf{0 . 0 7 1}$ \\
\hline
\end{tabular}

Note: 1 , significant level at $10 \%$

2, constant represent February

3 , the results show that there is no February effect in SHA and SZA by using adjusted value-weighted data. 
Table 5. Test results by using value-weighted data for March test on A-shares

Panel 1: Estimated coefficients by unadjusted data-MARCH, 1994-2006

\begin{tabular}{|c|cc|cc|}
\hline & \multicolumn{2}{|c|}{ SHA } & \multicolumn{2}{c|}{ SZA } \\
\hline Month & Coefficients & P-value & Coefficients & P-value \\
\hline Constant & $4.48 \%$ & $0.098^{*}$ & $2.69 \%$ & 0.330 \\
Jan. & $-4.52 \%$ & 0.237 & $-2.86 \%$ & 0.463 \\
Feb. & $-2.08 \%$ & 0.587 & $0.35 \%$ & 0.929 \\
Apr. & $-4.28 \%$ & 0.263 & $-2.09 \%$ & 0.592 \\
May. & $-2.58 \%$ & 0.499 & $-0.13 \%$ & 0.974 \\
Jun. & $-5.29 \%$ & 0.167 & $-4.29 \%$ & 0.272 \\
Jul. & $-4.11 \%$ & 0.282 & $-0.90 \%$ & 0.818 \\
Aug. & $-1.26 \%$ & 0.742 & $-1.47 \%$ & 0.705 \\
Sep. & $-4.94 \%$ & 0.196 & $-3.01 \%$ & 0.441 \\
Oct. & $-6.04 \%$ & 0.115 & $-2.64 \%$ & 0.499 \\
Nov. & $-2.68 \%$ & 0.483 & $-1.72 \%$ & 0.659 \\
Dec. & $-6.81 \%$ & $\mathbf{0 . 0 7 6 *}$ & $-6.89 \%$ & $\mathbf{0 . 0 7 9}$ \\
\hline
\end{tabular}

Note: $1, *$ significant level at $10 \%$

2, constant represent March

3, the results show that there is no clear March effect in both SHA and SZA by using unadjusted value-weighted data.

Panel 2: Estimated coefficients by adjusted data-MARCH, 1994-2006

\begin{tabular}{|c|cc|cc|}
\hline & \multicolumn{2}{|c|}{ SHA } & \multicolumn{2}{c|}{ SZA } \\
\hline Month & Coefficients & P-value & Coefficients & P-value \\
\hline Constant & $4.48 \%$ & $\mathbf{0 . 0 4 1}$ & $4.56 \%$ & 0.037 \\
Jan. & $-4.52 \%$ & 0.144 & $-4.73 \%$ & 0.117 \\
Feb. & $-2.08 \%$ & 0.502 & $-1.52 \%$ & 0.612 \\
Apr. & $-4.28 \%$ & 0.167 & $-6.99 \%$ & $\mathbf{0 . 0 2 4}$ \\
May. & $-4.12 \%$ & 0.192 & $-2.00 \%$ & 0.506 \\
Jun. & $-5.29 \%$ & $\mathbf{0 . 0 8 9} *$ & $-7.99 \%$ & $\mathbf{0 . 0 1 0}$ \\
Jul. & $-4.11 \%$ & 0.184 & $-5.68 \%$ & $0.065^{*}$ \\
Aug. & $-5.96 \%$ & $\mathbf{0 . 0 6 0} *$ & $-5.56 \%$ & $\mathbf{0 . 0 7 1}$ \\
Sep. & $-4.94 \%$ & 0.111 & $-4.88 \%$ & 0.106 \\
Oct. & $-6.04 \%$ & $\mathbf{0 . 0 5 2} *$ & $-5.02 \%$ & 0.110 \\
Nov. & $-2.68 \%$ & 0.386 & $-3.59 \%$ & 0.233 \\
Dec. & $-7.41 \%$ & $\mathbf{0 . 0 2 3} *$ & $-6.96 \%$ & $\mathbf{0 . 0 2 4}$ \\
\hline
\end{tabular}

Note: 1 * significant level at $10 \%$

2, constant represent March

3, the results show that there is March effect in both SHA and SZA by using adjusted value-weighted data.

Table 6. The size effect

The size effect for both A-share markets

\begin{tabular}{|c|cc|cc|}
\hline & \multicolumn{2}{|c|}{ SHA } & \multicolumn{2}{c|}{ SZA } \\
\hline Size & Average return & SD & Average return & SD \\
\hline $\mathbf{1}$ & $0.72 \%$ & $12.03 \%$ & $0.66 \%$ & $12.76 \%$ \\
$\mathbf{2}$ & $0.32 \%$ & $12.01 \%$ & $0.30 \%$ & $12.01 \%$ \\
$\mathbf{3}$ & $0.27 \%$ & $11.48 \%$ & $0.02 \%$ & $11.19 \%$ \\
$\mathbf{4}$ & $0.06 \%$ & $11.22 \%$ & $-0.12 \%$ & $10.79 \%$ \\
$\mathbf{5}$ & $-0.02 \%$ & $11.11 \%$ & $-0.22 \%$ & $10.08 \%$ \\
\hline
\end{tabular}

Note: 1 , Size 1 represents the smallest capitalization stocks and size 5 represents the largest capitalization stocks.

2, SD represents the risk level 
Table 7. Test results by using unadjusted equal-weighted data for March test on A- shares

Panel 1: Estimated coefficients by unadjusted data - MARCH, 1994-2006 on SHA

\begin{tabular}{|c|c|c|c|c|c|c|c|c|c|c|}
\hline \multicolumn{11}{|c|}{ SHA } \\
\hline & \multicolumn{2}{|c|}{1} & \multicolumn{2}{|c|}{2} & \multicolumn{2}{|c|}{3} & \multicolumn{2}{|c|}{4} & \multicolumn{2}{|c|}{5} \\
\hline Month & Coeff. & P-value & Coeff. & P-value & Coeff. & P-value & Coeff. & $P$-value & Coeff. & P-value \\
\hline Constant & $6.93 \%$ & 0.035* & $4.39 \%$ & 0.151 & $4.08 \%$ & 0.219 & $2.80 \%$ & 0.382 & $2.76 \%$ & 0.379 \\
\hline Jan. & $-7.26 \%$ & 0.117 & $-4.68 \%$ & 0.279 & $-4.37 \%$ & 0.352 & $-3.02 \%$ & 0.504 & $-2.97 \%$ & 0.504 \\
\hline Feb. & $-3.67 \%$ & 0.427 & $-1.16 \%$ & 0.788 & $-1.76 \%$ & 0.707 & $-0.84 \%$ & 0.853 & $-1.35 \%$ & 0.761 \\
\hline Apr. & $-7.35 \%$ & 0.113 & $-4.55 \%$ & 0.291 & $-3.29 \%$ & 0.482 & $-2.49 \%$ & 0.581 & $-2.66 \%$ & 0.549 \\
\hline May. & $-4.27 \%$ & 0.356 & $-2.36 \%$ & 0.584 & $-2.71 \%$ & 0.563 & $-1.74 \%$ & 0.699 & $-2.32 \%$ & 0.601 \\
\hline Jun. & $-7.76 \%$ & $0.095^{*}$ & $-5.12 \%$ & 0.236 & $-4.60 \%$ & 0.327 & $-2.59 \%$ & 0.566 & $-1.80 \%$ & 0.685 \\
\hline Jul. & $-11.86 \%$ & $0.011^{*}$ & $-9.64 \%$ & $0.027 *$ & $-9.32 \%$ & $0.048 *$ & $-7.51 \%$ & 0.098* & $-7.92 \%$ & $0.076 *$ \\
\hline Aug. & $1.39 \%$ & 0.764 & $2.73 \%$ & 0.527 & $3.99 \%$ & 0.395 & $3.90 \%$ & 0.388 & $2.80 \%$ & 0.528 \\
\hline Sep. & $-6.59 \%$ & 0.155 & $-5.06 \%$ & 0.241 & $-4.66 \%$ & 0.321 & $-3.47 \%$ & 0.443 & $-3.53 \%$ & 0.426 \\
\hline Oct. & $-9.11 \%$ & $0.05 *$ & $-6.69 \%$ & 0.122 & $-6.95 \%$ & 0.14 & $-5.52 \%$ & 0.223 & $-5.30 \%$ & 0.233 \\
\hline Nov. & $-5.75 \%$ & 0.214 & $-3.22 \%$ & 0.456 & $-3.08 \%$ & 0.511 & $-2.13 \%$ & 0.638 & $-1.79 \%$ & 0.686 \\
\hline Dec. & $-12.35 \%$ & 0.008* & $-9.08 \%$ & $0.036^{*}$ & $-8.93 \%$ & 0.058* & $-7.43 \%$ & 0.102 & $-6.56 \%$ & 0.14 \\
\hline
\end{tabular}

Note:

$1, *$ Significant level at $10 \%$

2 , size 1 represents the smallest capitalization stocks and size 5 represents the largest capitalization stocks.

3, constant represent March

4 , the results show that there is no March effect for SHA by using unadjusted equal-weighted data. The results indicate the highest return is August.

Panel 2: Estimated coefficients by unadjusted data-MARCH, 1994-2006 on SZA

\begin{tabular}{|c|c|c|c|c|c|c|c|c|c|c|}
\hline \multicolumn{11}{|c|}{ SZA } \\
\hline & \multicolumn{2}{|c|}{1} & \multicolumn{2}{|c|}{2} & \multicolumn{2}{|c|}{3} & \multicolumn{2}{|c|}{4} & \multicolumn{2}{|c|}{5} \\
\hline Month & Coeff. & P-value & Coeff. & P-value & Coeff. & P-value & Coeff. & P-value & Coeff. & P-value \\
\hline Constant & $4.14 \%$ & 0.247 & $2.94 \%$ & 0.383 & $2.50 \%$ & 0.426 & $1.46 \%$ & 0.630 & $1.11 \%$ & 0.696 \\
\hline Jan. & $-4.98 \%$ & 0.325 & $-4.41 \%$ & 0.355 & $-3.31 \%$ & 0.455 & $-2.15 \%$ & 0.617 & $-1.58 \%$ & 0.695 \\
\hline Feb. & $0.13 \%$ & 0.979 & $0.34 \%$ & 0.943 & $0.01 \%$ & 0.999 & $0.68 \%$ & 0.874 & $0.62 \%$ & 0.877 \\
\hline Apr. & $-4.98 \%$ & 0.325 & $-2.42 \%$ & 0.612 & $-2.82 \%$ & 0.525 & $-0.57 \%$ & 0.894 & $-0.17 \%$ & 0.967 \\
\hline May. & $-1.63 \%$ & 0.746 & $-0.72 \%$ & 0.879 & $-1.65 \%$ & 0.709 & $0.63 \%$ & 0.884 & $0.14 \%$ & 0.972 \\
\hline Jun. & $-3.79 \%$ & 0.453 & $-3.22 \%$ & 0.499 & $-1.56 \%$ & 0.725 & $-1.13 \%$ & 0.793 & $-0.57 \%$ & 0.888 \\
\hline Jul. & $-7.07 \%$ & 0.162 & $-5.74 \%$ & 0.229 & $-5.98 \%$ & 0.179 & $-4.69 \%$ & 0.276 & $-4.30 \%$ & 0.288 \\
\hline Aug. & $0.55 \%$ & 0.914 & $1.27 \%$ & 0.790 & $1.67 \%$ & 0.706 & $1.04 \%$ & 0.808 & $0.67 \%$ & 0.868 \\
\hline Sep. & $-1.65 \%$ & 0.744 & $-2.38 \%$ & 0.618 & $-2.95 \%$ & 0.507 & $-2.51 \%$ & 0.559 & $-2.63 \%$ & 0.514 \\
\hline Oct. & $-4.05 \%$ & 0.423 & $-2.65 \%$ & 0.578 & $-3.27 \%$ & 0.461 & $-1.75 \%$ & 0.683 & $-2.12 \%$ & 0.599 \\
\hline Nov. & $-3.81 \%$ & 0.450 & $-2.39 \%$ & 0.616 & $-1.45 \%$ & 0.744 & $-1.16 \%$ & 0.786 & $-0.40 \%$ & 0.921 \\
\hline Dec. & $-10.50 \%$ & 0.039 & $-9.45 \%$ & 0.049 & $-8.49 \%$ & 0.057 & $-7.38 \%$ & 0.087 & $-5.65 \%$ & 0.163 \\
\hline
\end{tabular}

Note: $1,{ }^{*}$ Significant level at $10 \%$

2 , size 1 represents the smallest capitalization stocks and size 5 represents the largest capitalization stocks.

3, constant represent March

4, the results show that there is no March effect for SZA by using unadjusted equal-weighted data. 
Table 8. Test results by using adjusted Equal-weighted data for March effect on A-shares

Panel 1: Estimated coefficients by adjusted data-MARCH, 1994-2006 on SHA

\begin{tabular}{|c|c|c|c|c|c|c|c|c|c|c|}
\hline \multicolumn{11}{|c|}{ SHA } \\
\hline & \multicolumn{2}{|c|}{1} & \multicolumn{2}{|c|}{2} & \multicolumn{2}{|c|}{3} & \multicolumn{2}{|c|}{4} & \multicolumn{2}{|c|}{5} \\
\hline Month & Coeff. & P-value & Coeff. & P-value & Coeff. & P-value & Coeff. & P-value & Coeff. & P-value \\
\hline Constant & $6.93 \%$ & 0.003* & $4.39 \%$ & 0.041* & $4.08 \%$ & 0.064* & $2.80 \%$ & 0.202 & $2.76 \%$ & 0.18 \\
\hline Jan. & $-7.26 \%$ & $0.028 *$ & $-4.68 \%$ & 0.123 & $-4.37 \%$ & 0.16 & $-3.02 \%$ & 0.329 & $-2.97 \%$ & 0.309 \\
\hline Feb. & $-3.67 \%$ & 0.265 & $-1.16 \%$ & 0.701 & $-1.76 \%$ & 0.57 & $-0.84 \%$ & 0.787 & $-1.35 \%$ & 0.643 \\
\hline Apr. & $-9.48 \%$ & $0.005 *$ & $-6.45 \%$ & $0.038^{*}$ & $-3.29 \%$ & 0.289 & $-4.45 \%$ & 0.16 & $-2.66 \%$ & 0.361 \\
\hline May. & $-4.27 \%$ & 0.195 & $-2.36 \%$ & 0.434 & $-2.71 \%$ & 0.383 & $-1.74 \%$ & 0.573 & $-2.32 \%$ & 0.425 \\
\hline Jun. & $-9.96 \%$ & $0.003^{*}$ & $-7.28 \%$ & $0.019^{*}$ & $-7.13 \%$ & $0.026 *$ & $-4.87 \%$ & 0.124 & $-4.09 \%$ & 0.17 \\
\hline Jul. & $-9.04 \%$ & $0.008 *$ & $-6.83 \%$ & $0.028 *$ & $-6.54 \%$ & $0.04 *$ & $-4.91 \%$ & 0.121 & $-5.51 \%$ & $0.065 *$ \\
\hline Aug. & $-5.50 \%$ & $0.10 *$ & $-3.75 \%$ & 0.225 & $-3.81 \%$ & 0.23 & $-3.21 \%$ & 0.309 & $-4.70 \%$ & 0.115 \\
\hline Sep. & $-6.59 \%$ & $0.047 *$ & $-5.06 \%$ & 0.095* & $-4.66 \%$ & 0.134 & $-3.47 \%$ & 0.263 & $-3.53 \%$ & 0.225 \\
\hline Oct. & $-9.11 \%$ & 0.006* & $-6.69 \%$ & 0.028* & $-6.95 \%$ & $0.026 *$ & $-5.52 \%$ & 0.076* & $-5.30 \%$ & $0.07 *$ \\
\hline Nov. & $-5.75 \%$ & $0.082 *$ & $-3.22 \%$ & 0.287 & $-3.08 \%$ & 0.321 & $-2.13 \%$ & 0.491 & $-1.79 \%$ & 0.537 \\
\hline Dec. & $-12.35 \%$ & $0.000 *$ & $-9.08 \%$ & 0.003* & $-9.65 \%$ & 0.003* & $-7.43 \%$ & $0.017 *$ & $-7.64 \%$ & 0.011* \\
\hline
\end{tabular}

Note: $1, *$ Significant level at $10 \%$

2 , size 1 represents the smallest capitalization stocks and size 5 represents the largest capitalization stocks.

3 , constant represent March

4, the results show that a significant March effect has been observed by using adjusted value-weighted data on SHA. The results also suggest that the evidence on smallest capitalization stocks is stronger than large capitalization stocks.

Panel 2: Estimated coefficients by adjusted data-MARCH, 1994-2006 on SZA

\begin{tabular}{|c|c|c|c|c|c|c|c|c|c|c|}
\hline \multicolumn{11}{|c|}{ SZA } \\
\hline & \multicolumn{2}{|c|}{1} & \multicolumn{2}{|c|}{2} & \multicolumn{2}{|c|}{3} & \multicolumn{2}{|c|}{4} & \multicolumn{2}{|c|}{5} \\
\hline Month & Coeff. & P-value & Coeff. & P-value & Coeff. & P-value & Coeff. & P-value & Coeff. & P-value \\
\hline Constant & $5.76 \%$ & 0.019* & $4.75 \%$ & 0.045 & $4.26 \%$ & 0.053 & $3.07 \%$ & 0.164 & $3.08 \%$ & 0.142 \\
\hline Jan. & $-6.60 \%$ & 0.053* & $-6.21 \%$ & 0.058* & $-5.07 \%$ & 0.096* & $-3.75 \%$ & 0.219 & $-3.55 \%$ & 0.223 \\
\hline Feb. & $-1.49 \%$ & 0.660 & $-1.46 \%$ & 0.653 & $-1.75 \%$ & 0.564 & $-0.92 \%$ & 0.762 & $-1.35 \%$ & 0.642 \\
\hline Apr. & $-9.53 \%$ & $0.006 *$ & $-7.00 \%$ & $0.036 *$ & $-7.54 \%$ & 0.016* & $-5.46 \%$ & $0.081 *$ & $-4.93 \%$ & $0.097 *$ \\
\hline May. & $-3.26 \%$ & 0.337 & $-2.53 \%$ & 0.437 & $-3.41 \%$ & 0.262 & $-0.98 \%$ & 0.748 & $-1.83 \%$ & 0.528 \\
\hline Jun. & $-5.47 \%$ & 0.122 & $-5.27 \%$ & 0.122 & $-5.67 \%$ & 0.068* & $-4.93 \%$ & 0.114 & $-5.14 \%$ & $0.084 *$ \\
\hline Jul. & $-9.69 \%$ & $0.007 *$ & $-8.52 \%$ & $0.013 *$ & $-8.96 \%$ & $0.005^{*}$ & $-7.63 \%$ & $0.017 *$ & $-9.00 \%$ & $0.003^{*}$ \\
\hline Aug. & $-6.26 \%$ & 0.071* & $-5.84 \%$ & 0.080* & $-4.75 \%$ & 0.126 & $-4.31 \%$ & 0.167 & $-4.66 \%$ & 0.117 \\
\hline Sep. & $-5.95 \%$ & $0.086 *$ & $-4.18 \%$ & 0.200 & $-4.70 \%$ & 0.122 & $-4.12 \%$ & 0.178 & $-4.60 \%$ & 0.115 \\
\hline Oct. & $-9.38 \%$ & $0.007 *$ & $-7.79 \%$ & 0.020* & $-5.95 \%$ & 0.062* & $-4.33 \%$ & 0.174 & $-4.42 \%$ & 0.145 \\
\hline Nov. & $-5.43 \%$ & 0.110 & $-4.19 \%$ & 0.199 & $-3.21 \%$ & 0.291 & $-2.77 \%$ & 0.364 & $-2.37 \%$ & 0.415 \\
\hline Dec. & $-9.09 \%$ & 0.009* & $-8.84 \%$ & 0.009* & $-8.10 \%$ & 0.010* & $-6.89 \%$ & 0.028* & $-5.62 \%$ & 0.059* \\
\hline
\end{tabular}

Note: $1, *$ Significant level at $10 \%$

2, size 1 represents the smallest capitalization stocks and size 5 represents the largest capitalization stocks.

3 , constant represent March

4, the results show that a significant March effect has been observed by using adjusted value-weighted data on SZA. The results also suggest that the evidence on smallest capitalization stocks is stronger than large capitalization stocks.

Table 9. The timetable for Chinese New Years

\begin{tabular}{|ccc|}
\hline \multicolumn{3}{|c|}{ Chinese New Year } \\
\hline Year & Beginning & Ending \\
\hline 1993 & $23-J a n$ & $6-\mathrm{Feb}$ \\
1994 & 10-Feb & $24-\mathrm{Feb}$ \\
1995 & 31-Jan & $14-\mathrm{Feb}$ \\
1996 & 19-Feb & $4-\mathrm{Mar}$ \\
1997 & $7-\mathrm{Feb}$ & $21-\mathrm{Feb}$ \\
1998 & $28-\mathrm{Jan}$ & $11-\mathrm{Feb}$ \\
1999 & 16-Feb & $2-\mathrm{Mar}$ \\
2000 & 5-Feb & $19-\mathrm{Feb}$ \\
2001 & $24-\mathrm{Jan}$ & $7-\mathrm{Feb}$ \\
2002 & 12-Feb & $26-\mathrm{Feb}$ \\
2003 & 1-Feb & $15-\mathrm{Feb}$ \\
2004 & $22-\mathrm{Jan}$ & $5-\mathrm{Feb}$ \\
2005 & 9-Feb & $23-\mathrm{Feb}$ \\
2006 & 28-Feb & $12-\mathrm{Feb}$ \\
\hline
\end{tabular}

Note: The ending date calculated as Chinese traditionally new year ending which is the Lantern Festival. 